\title{
MODE OF ACTION AND IN VITRO SUSCEPTIBILITY OF MASTITIS PATHOGENS TO MACEDOCIN ST91KM AND PREPARATION OF A TEAT SEAL CONTAINING THE BACTERIOCIN
}

\author{
Renee Pieterse, Svetoslav D. Todorov*, Leon M.T. Dicks
}

Department of Microbiology, University of Stellenbosch, 7600 Stellenbosch, South Africa

Submitted: November 26, 2008; Returned to authors for corrections: April 20, 2009; Approved: July 22, 2009.

\begin{abstract}
Mastitis is considered to be the most economically costly disease affecting the dairy industry. Regular dosage of animals with antibiotics, including use of prophylactic concentrations, may select for resistant strains. The purpose of this study was to determine the mode of action of a new bacteriocin (macedocin ST91KM), to evaluate the antimicrobial resistance of mastitis pathogens to antibiotics commonly used in treatment remedies, and to introduce the possible use of an alternative antimicrobial agent. The bacteriocin macedocin ST91KM, produced by Streptococcus gallolyticus subsp. macedonicus ST91KM, is bactericidal to Streptococcus agalactiae, Streptococcus dysgalactiae, Streptococcus uberis and Staphylococcus aureus associated with mastitis infections, including strains resistant to methicillin and oxacillin. Sensitive cells were deformed and secreted nucleotides, $\mathrm{K}^{+}$and $\beta$-galactosidase when exposed to macedocin ST91KM. Adsorption of the peptide to target cells decreased in the presence of solvents, suggesting that receptors on the cell surfaces have lipid moieties. No adsorption was recorded in the presence of $\mathrm{MgCl}_{2}, \mathrm{KI}$ and $\mathrm{Na}_{2} \mathrm{CO}_{3}$, suggesting that ionic strength plays an important role. A teat seal preparation containing macedocin ST91KM effectively released the peptide and inhibited the growth of S. agalactiae. Macedocin ST91KM could form the basis for alternative dry cow therapy to prevent mastitis infections in dairy cows as it is effective against pathogens that display resistance to conventional antibiotic therapy.
\end{abstract}

Key words: Macedocin ST91KM; activity against mastitis pathogens; teat seal preparation; milk

\section{INTRODUCTION}

Mastitis concerns cows is primarily caused by infection with Staphylococcus aureus, Streptococcus agalactiae, Streptococcus uberis, Streptococcus dysgalactiae and Escherichia coli (25). After entering the mammary gland through the teat canal, the bacteria multiply rapidly, leading to inflammation and tissue damage (9). Antibiotics are routinely administered at drying-off to treat sub clinical cases of mastitis and prevent further infection (4,37). Although fairly successful, this practice may lead to the development of antibiotic resistant strains, as reported for coagulase-negative staphylococci, $S$. aureus and streptococci $(6,8,20,28)$. If any of these strains are present in a dairy product, it may lead to transfer of antibiotic resistance genes to normal intestinal microorganisms $(14,15,16,17)$. 
Bacteriocins are ribosomally synthesized peptides, usually active against bacteria of the same or closely related species (12). These peptides produced by lactic acid bacteria are generally considered safe and may present a cost-effective alternative to treat mastitis caused by $S$. aureus, S. agalactiae and S. dysgalactiae. In a study which involved the incorporation of the bacteriocin lacticin 3147 into a teat seal (1280AU/mL), $99.9 \%$ of S. aureus cells were killed (30). Peptide AS-48, produced by Enterococcus faecalis FAIRE 92, inhibited the growth of a $S$. aureus strain isolated from mastitic milk (5). Treatment of $S$. aureus-infected udders with liposome-encapsulated peptide AS-48 (6400AU/mL) resulted in an $85 \%$ reduction in somatic cell counts and a $99 \%$ reduction in viable cell numbers of $S$. aureus (5).

Streptococcus gallolyticus subsp. macedonicus ST91KM, isolated from Bulgarian goat yoghurt, produces the bacteriocin macedocin ST91KM (26). The peptide has a narrow spectrum of antibacterial activity and inhibits the growth of Lactobacillus sakei, S. agalactiae, S. dysgalactiae, Streptococcus uberis, S. aureus and Staphylococcus epidermidis. The peptide is approximately $2.0-2.5 \mathrm{kDa}$ in size and remained stable after incubation for $2 \mathrm{~h}$ at $\mathrm{pH} 2.0$ to 10.0 . No decrease in activity was recorded after treatment at $100^{\circ} \mathrm{C}$ for $100 \mathrm{~min}$, but the peptide was inactivated at $121^{\circ} \mathrm{C}$ for 20min. No change in activity was recorded after treatment with SDS, urea, Tween 20, Tween 80 and EDTA. Treatment with pronase, pepsin and trypsin inactivated the bacteriocin.

As far as we could determine, only one other bacteriocin has been described for $S$. macedonicus, i.e. the lantibiotic macedocin produced by S. macedonicus ACA-DC 198 (7).

In this study, parameters affecting the adsorption and some aspects of the mode of action of macedocin ST91KM to target organisms were evaluated. Minimum inhibitory concentration (MIC) of macedocin ST91KM was determined and compared to that of $\beta$-lactam penicillins and erythromycin. Macedocin ST91KM was incorporated in a teat seal preparation and its activity against $S$. agalactiae studied in vitro.

\section{MATERIALS AND METHODS}

\section{Growth conditions and preparation of macedocin ST91KM}

Streptococcus gallolyticus subsp. macedonicus ST91KM was grown in MRS broth (Biolab, Biolab Diagnostics, Midrand, SA) at $30^{\circ} \mathrm{C}$. The target strains used in the study were grown either in MRS broth or BHI broth (Merck, Darmstadt, Germany), at temperatures indicated in the respective culture collection catalogues. $S$. agalactiae RPSAG2, isolated from a clinical mastitis case, was obtained from the Western Cape Provincial Veterinary Laboratory (Stellenbosch, South Africa) and was cultured in BHI broth at $37^{\circ} \mathrm{C}$. All strains were stored at $-80^{\circ} \mathrm{C}$ in $\mathrm{MRS}$ or $\mathrm{BHI}$ supplemented with $40 \%$ (v/v) glycerol.

Macedocin ST91KM was prepared as follows: Strain ST91KM was inoculated (2\%, v/v) into $100 \mathrm{~mL}$ MRS and incubated for $17 \mathrm{~h}$ at $30^{\circ} \mathrm{C}$. The cells were harvested $(1000 \mathrm{xg}$, $\left.10 \mathrm{~min}, 4^{\circ} \mathrm{C}\right)$, the $\mathrm{pH}$ of the cell-free culture supernatant adjusted to 6.0 with $1 \mathrm{M} \mathrm{NaOH}$, and then heated for $10 \mathrm{~min}$ at $80^{\circ} \mathrm{C}$ to inactivate proteolytic enzymes. The supernatant was filter-sterilised $\left(0.20 \mu \mathrm{m}\right.$ pore size membrane, Minisart ${ }^{\circledR}$, Sartorius, Aubagne, France) and the activity of macedocin ST91KM determined by using the agar-spot method (36). Active samples of macedocin ST91KM were stored at $4^{\circ} \mathrm{C}$.

\section{Antimicrobial activity assays}

Overnight cultures of the target strains $\left(\mathrm{OD}_{600 \mathrm{~nm}}=0.1-0.2\right)$, listed in Table 1 , were inoculated $(0.1 \%$, v/v) into $10 \mathrm{~mL}$ MRS or BHI soft agar $(0.7 \%, \mathrm{w} / \mathrm{v}$, agar), poured into sterile Petri dishes and allowed to solidify. A dilution series of macedocin ST91KM was prepared and $10 \mu \mathrm{L}$ spotted onto the surface of the solid media. Antimicrobial activity was expressed in arbitrary units $(\mathrm{AU}) / \mathrm{mL}$, calculated as follows: $\mathrm{a}^{\mathrm{b}} \times 100$, where "a" represents the dilution factor 2 and " $b$ " the last dilution that produces an inhibition zone of at least $2 \mathrm{~mm}$ in diameter. Activity was expressed per mL by multiplication with 100 (36). 
Table 1. Activity spectrum of macedocin ST91KM and adsorption to target cells

\section{macedocin ST91KM}

\begin{tabular}{lcc} 
Target organism & $\begin{array}{l}\text { Sensitivity to macedocin } \\
\text { ST91KM }\end{array}$ & Adsorption (\%) \\
\hline E. faecalis BFE1071 and FAIR-E92 & - & 66 \\
E. mundtii ST4SA & - & 0 \\
Enterococcus sp. HKLHS & - & 33 \\
L. curvatus DF38 & - & 33 \\
L. plantarum LMG13556 & - & 33 \\
L. salvarius 241 & - & 33 \\
L. sakei LMG13558 & + & 66 \\
Lactococcus lactis subsp. lactis HV219 & - & 0 \\
L. innocua LMG13568 & - & 33 \\
S. caprinus ATCC700066 & - & 66
\end{tabular}

${ }^{\mathrm{a}}$ - = not inhibited, and $+=$ inhibited by macedocin ST91KM

Effect of macedocin ST91KM on cell growth and membrane permeability

S. agalactiae RPSAG2 was grown in $50 \mathrm{~mL}$ BHI broth (Merck) for $5 \mathrm{~h}$ at $37^{\circ} \mathrm{C}$ to an optical density of 0.17 . Twenty $\mathrm{mL}$ macedocin ST91KM was added to the culture, representing a final macedocin ST91KM concentration of $230 \mathrm{AU} / \mathrm{mL}$. Optical density readings were recorded every hour for $10 \mathrm{~h}$. The control was S. agalactiae RPSAG2 cultured in the same way, but to which $20 \mathrm{~mL}$ sterile distilled water was added. The experiment was repeated in triplicate.

In a separate experiment, an overnight culture of $L$. sakei LMG13558 $\left(\mathrm{OD}_{600 \mathrm{~nm}}=2.2\right)$ was harvested $(8000 \mathrm{xg}, 15 \mathrm{~min}$, $25^{\circ} \mathrm{C}$ ), the cells washed twice with $2.0 \mathrm{~mL} 5 \mathrm{mM}$ phosphate buffer $(\mathrm{pH}$ 6.5), and then incubated in the presence of macedocin ST91KM (0.1:10 ratio). After $1 \mathrm{~h}$ at $37^{\circ} \mathrm{C}$, the cells were harvested $\left(10000 \mathrm{xg}, 15 \mathrm{~min}, 4^{\circ} \mathrm{C}\right)$ and the supernatant filtered through a $0.20 \mu \mathrm{m}$ pore size filter membrane (Ministart $^{\circledR}$, Sartorius). The presence of nuclear material was recorded by absorbance readings at 260nm (SmartSpec ${ }^{\text {TM }}$ Plus Spectrophotometer, Bio-Rad Laboratories, Hecules, CA USA). The presence of $\mathrm{K}^{+}$in the filtrate was determined by atomic absorption spectrometry (Avanta $\Sigma$, GBC Scientific
Equipment, Victoria, Australia). Controls were cells prepared the same way, but not treated with macedocin ST91KM.

In another experiment, extracellular levels of $\beta$ galactosidase activity were determined according to the methods of Nagy et al. (22) and Hsu et al. (10). Cells of $L$. sakei LMG13558 were harvested $\left(10000 \mathrm{xg}, 15 \mathrm{~min}, 25^{\circ} \mathrm{C}\right)$ after $11 \mathrm{~h}$ incubation at $30^{\circ} \mathrm{C}$, washed twice with $0.03 \mathrm{M}$ sodium phosphate buffer ( $\mathrm{pH} 6.8$ ) and then re-suspended in $2.0 \mathrm{~mL}$ of the same buffer. The cell suspension was treated with $2 \mathrm{~mL}$ macedocin ST91KM $(800 \mathrm{AU} / \mathrm{mL})$ for $5 \mathrm{~min}$ at $25^{\circ} \mathrm{C}$, followed by the addition of $0.2 \mathrm{~mL} 0.1 \mathrm{M}$ ONPG (O-nitrophenyl- $\beta$-Dgalactopyranoside) in $0.03 \mathrm{M}$ sodium phosphate buffer $(\mathrm{pH}$ 6.8). After $10 \mathrm{~min}$ incubation at $37^{\circ} \mathrm{C}$ for $10 \mathrm{~min}, 2.0 \mathrm{~mL} 0.1 \mathrm{M}$ sodium carbonate was added to stop the reaction of $\beta$ galactosidase. The cells were harvested $(10000 \mathrm{xg}, 15 \mathrm{~min}$, $25^{\circ} \mathrm{C}$ ) and absorbance readings of the cell-free culture supernatant recorded at $420 \mathrm{~nm}$, using a spectrophotometer (SmartSpec ${ }^{\mathrm{TM}}$ Plus Spectrophotometer). Cells of L. sakei LMG 13558 treated with sterile water instead of macedocin ST91KM served as control. All experiments were performed in duplicate. 


\section{Adsorption of macedocin ST91KM to target cells}

Adsorption to target cells (Table 1) was tested according to Yildrim et al. (38). The bacterial strains were grown overnight in MRS or BHI broth at $37^{\circ} \mathrm{C}$ to $\mathrm{OD}_{600 \mathrm{~nm}}=0.1-0.2$ and the cells harvested $\left(10000 \mathrm{xg}, 15 \mathrm{~min}, 4^{\circ} \mathrm{C}\right)$. Cells were washed twice in $5 \mathrm{mM}$ phosphate buffer ( $\mathrm{pH}$ 6.5) and resuspended in the same buffer to the original volume. Each cell suspension $(0.7 \mathrm{~mL})$ was mixed with an equal volume of macedocin ST91KM and incubated at $37^{\circ} \mathrm{C}$ for $1 \mathrm{~h}$. The cells were harvested (10000xg for $15 \mathrm{~min})$ and activity of unbound macedocin ST91KM in the cell-free supernatant determined using the agar-spot method as described before. Adsorption of macedocin ST91KM to the target cells was calculated according to the following formula: \% Adsorption $=100-$ [(macedocin ST91KM activity after treatment/original macedocin ST91KM activity) x 100]. The experiment was performed in triplicate.

\section{Effect of $\mathrm{pH}$ and temperature on adsorption of macedocin ST91KM to L. sakei}

Cells from an overnight culture of L. sakei LMG 13558 $\left(\mathrm{OD}_{600 \mathrm{~nm}}=2.2\right)$ were harvested and re-suspended in original volume of physiological water and the $\mathrm{pH}$ corrected to values between 2.0 and 10.0 with sterile $1 \mathrm{M} \mathrm{NaOH}$ or $1 \mathrm{M} \mathrm{HCl} \mathrm{(36).}$ Macedocin ST91KM was added to the cell suspension and incubated at $4,10,25,30,37,45$ and $60^{\circ} \mathrm{C}$ for $1 \mathrm{~h}$. The cells were harvested $\left(10000 \mathrm{xg}, 15 \mathrm{~min}, 25^{\circ} \mathrm{C}\right)$ and the $\mathrm{pH}$ of the supernatants adjusted to 6.0 with sterile $1 \mathrm{M} \mathrm{NaOH}$. Macedocin ST91KM activity was determined as described before. All experiments were performed in triplicate.

\section{Effect of surfactants, inorganic salts and organic} compounds on the adsorption of macedocin ST91KM to $L$. sakei

Cell suspensions of L. sakei LMG 13558 were prepared as described before and were treated with $1 \%(w / v) \mathrm{NaCl}$, $\mathrm{K}_{2} \mathrm{HPO}_{4}, \mathrm{KH}_{2} \mathrm{PO}_{4}, \mathrm{MgCl}_{2}, \mathrm{KCl}, \mathrm{KI}$, Tris, $\left(\mathrm{NH}_{4}\right)_{3} \mathrm{C}_{6} \mathrm{H}_{5} \mathrm{O}_{7}$, $\mathrm{CH}_{3} \mathrm{COONa}, \mathrm{Na}_{2} \mathrm{CO}_{3}$, EDTA $\left(\mathrm{C}_{10} \mathrm{H}_{16} \mathrm{O}_{8} \mathrm{~N}_{2}\right)$, SDS and $1 \%(\mathrm{v} / \mathrm{v})$ Triton X-100, Triton X-114, $\beta$-mercaptoethanol, and $80 \%$ (v/v) ethanol, methanol and chloroform, respectively (36). The $\mathrm{pH}$ of each suspension was adjusted to 6.5 with $1 \mathrm{M} \mathrm{NaOH}$ or $1 \mathrm{M}$ $\mathrm{HCl}$. Macedocin ST91KM was added to the treated cells, as before, and incubated at $37^{\circ} \mathrm{C}$ for $1 \mathrm{~h}$. The cells were harvested $\left(10000 \mathrm{xg}, 15 \mathrm{~min}, 25^{\circ} \mathrm{C}\right)$ and activity of the cell-free supernatant determined as before. The experiment was performed in triplicate.

\section{Effect of macedocin ST91KM on cell morphology}

Strain ST91KM was cultured in MRS broth for $15 \mathrm{~h}$ at $30^{\circ} \mathrm{C}$. The cells were harvested $\left(8000 \mathrm{xg}, 10 \mathrm{~min}, 4^{\circ} \mathrm{C}\right)$ and the bacteriocin precipitated from the cell-free culture supernatant with $60 \%$ saturated ammonium sulphate (31). The precipitate was suspended in $25 \mathrm{mM}$ ammonium acetate buffer ( $\mathrm{pH}$ 6.5) to one-tenth of the original volume and loaded onto a SepPak $\mathrm{C}_{18}$ cartridge (Water Millipore, MA, USA). Peptides were eluted with $20 \%, 40 \%, 60 \%$ and $80 \%$ (v/v) isopropanol, respectively, in $25 \mathrm{mM}$ ammonium acetate buffer ( $\mathrm{pH}$ 6.5) according Todorov et al. (35). Fractions of $1 \mathrm{~mL}$ were dried under vacuum at $50^{\circ} \mathrm{C}$ and stored at $-20^{\circ} \mathrm{C}$ until required.

Cells from an overnight culture $\left(\mathrm{OD}_{600 \mathrm{~nm}}=0.16\right)$ of $S$. agalactiae RPSAG2 were harvested $\left(8000 \mathrm{xg}, 10 \mathrm{~min}, 4^{\circ} \mathrm{C}\right)$ and washed five times with sterile distilled water. The dried bacteriocin fractions of macedocin ST91KM were reconstituted and concentrated with milliQ water, filter-sterilised $(0.20 \mu \mathrm{m}$ pore size membrane filter, Minisart ${ }^{\circledR}$, Sartorius Aubagne, France) and incubated with the prepared cells overnight at $8^{\circ} \mathrm{C}$ (approximately 2000AU/mL). The cells were then washed five times with sterile distilled water and re-suspended in $1 \mathrm{~mL}$ sterile distilled water. Untreated cells of $S$. agalactiae RPSAG2 served as control. Images of cell surface areas of treated and untreated cells were visualised by atomic force microscopy (Multimode AFM from Veeco, Santa Barbara USA). The cell suspension was applied onto freshly cleaved mica surface and allowed to dry for $5 \mathrm{~min}$ before subjected to AFM. All images were obtained in air and with tapping mode. A silicone non-contact cantilever from Nansensors (Neuchatel, Switzerland) with a resonance frequency of $160 \mathrm{kHz}$ and a spring constant of approximately $50 \mathrm{~N} / \mathrm{m}$ was used. Height and size information was acquired by using imaging software from Veeco. 


\section{Antimicrobial agents}

Peptide ST91KM, eluted from a SepPak $\mathrm{C}_{18}$ cartridge with $40 \%$ (v/v) isopropanol, as desribed before, were used for antimicrobial activity tests. The antibiotics used in this study were selected based on their approval and frequent use in the treatment of mastitis in South Africa. The antimicrobial agents selected included $\beta$-lactam penicillins: Penicillin G (PEN) (USB, Amersham Life Science), ampicillin (AMP) (Roche Diagnostics, Mannhein, Germany), oxacillin (OX) (SigmaAldrich, St. Louis, USA), methicillin (MET) (Sigma-Aldrich, St. Louis, USA) and a macrolide antibiotic, erythromycin (EM) (Sigma-Aldrich, St. Louis, USA). The antimicrobial agents were diluted in sterile deionised water to prepare stock solutions, each containing $1280 \mu \mathrm{g} / \mathrm{mL}$ of the active antibiotic. The final concentration range used for antimicrobial activity tests for each antibiotic was 32.0, 16.0, 8.0, 4.0, 2.0, 1.0, 0.5, 0.25 and $0.12 \mu \mathrm{g} / \mathrm{mL}$.

\section{Antimicrobial activity tests}

Minimum inhibitory concentration (MIC) tests were performed using the microdilution broth method, with Ubottomed 96-well microtitre plates, recommended by the Clinical and Laboratory Standards Institute (CLSI) (23). The antimicrobial agents are listed in Table 4. Serial two-fold dilutions of each antimicrobial agent were prepared in cationadjusted Mueller-Hinton broth (CAMHB) (Oxoid) and $50 \mu \mathrm{L}$ pipetted into the wells of sterile microtitre plates. A positive control well contained $50 \mu \mathrm{L}$ CAMHB, without an antimicrobial agent. Inoculum for each test organism (listed in Table 4) was prepared as follows: Three to five colonies were selected from a 24-h-old agar plate culture and suspended in $2 \mathrm{~mL}$ sterile $0.85 \%$ saline. The turbidity was adjusted to 0.5 according to the MacFarland standard. Ten $\mu \mathrm{L}$ of this suspension was transferred to $10 \mathrm{~mL}$ CAMHB to obtain a bacterial suspension of approximately $5 \times 10^{5} \mathrm{CFU} / \mathrm{mL}$. From this suspension, $50 \mu \mathrm{L}$ was pipetted into each well. The microtitre plates were sealed and incubated for $20 \mathrm{~h}$ at $37^{\circ} \mathrm{C}$. The MIC was defined as the lowest concentration of the antimicrobial agent at which the bacterial growth was completed inhibited as detected by the unaided eye. MIC breakpoints were used to determine resistance and susceptibility for each antibiotic tested. The exact concentration of peptide ST91KM in the bacteriocin preparations was unknown, therefore the antimicrobial activity of the peptide was expressed as arbitrary units per millilitre (AU/mL), calculated as follows: $\mathrm{a}^{\mathrm{b}} \mathrm{x} 20$, where " $\mathrm{a}$ " is equal to 2 , and " $b$ " the lowest dilution of the antimicrobial agent that prevented visible growth of the microorganisms tested. Activity was expressed per millilitre by multiplication with 20 . The protein concentration, expressed as $\mathrm{mg} / \mathrm{mL}$, in the bacteriocin preparations was assayed using the Bradford method. The final minimum inhibitory concentration of macedocin ST91KM was expressed as AU/mL protein.

\section{Teat seal formulation with macedocin ST91KM}

Macedocin ST91KM, precipitated from culture supernatant with ammonium sulphate, as described before, was suspended in $25 \mathrm{mM}$ ammonium acetate buffer ( $\mathrm{pH} 6.5$ ) to onetenth of its original volume. The teat seal consisted of $65 \%$ (w/w) bismuth subnitrate in a paraffin base, similar in composition to that of commercially available intramammary teat sealers such as Orbeseal (Pfizer Animal Health). A second formulation containing $1 \%(\mathrm{w} / \mathrm{w})$ Tween 80 in the teat seal paste was also prepared. Macedocin ST91KM $(100 \mu \mathrm{L})$ was added to $1 \mathrm{~g}$ of the teat seal paste with or without $1 \%(\mathrm{w} / \mathrm{w})$ Tween 80 and mixed to form an emulsion. The teat seal formulations were kept in $5 \mathrm{~mL}$ sterile syringes at $4^{\circ} \mathrm{C}$.

\section{In vitro effect of macedocin ST91KM combined with the teat seal against $S$. agalactiae}

The bacteriocin activity of macedocin ST91KM was determined using the agar well diffusion method. An overnight culture of $S$. agalactiae RPSAG2 was diluted by inoculating $10 \mu \mathrm{L}$ in $10 \mathrm{~mL}$ sterile physiological saline. One $\mathrm{mL}$ was inoculated into $9 \mathrm{~mL}$ semi-solid $(0.7 \%, \mathrm{w} / \mathrm{v})$ BHI agar (BHI Broth, Merck, Darmstadt, Germany) and wells of $4.6 \mathrm{~mm}$ made 


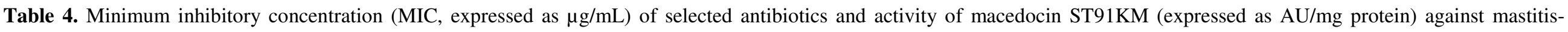
causing pathogens

\begin{tabular}{|c|c|c|c|c|c|c|c|c|c|c|c|c|c|c|c|}
\hline \multirow[b]{3}{*}{ Organism } & \multirow[b]{3}{*}{ Strain } & \multirow{2}{*}{\multicolumn{10}{|c|}{ MIC $(\mu \mathrm{g} / \mathrm{mL})$ of antibiotics ${ }^{\mathrm{a}}$}} & \multicolumn{4}{|c|}{ Macedocin ST91KM Activity } \\
\hline & & & & & & & & & & & & \multicolumn{2}{|c|}{ ST91KMppt. $^{\mathrm{c}}$} & \multicolumn{2}{|c|}{ ST91KMcon $^{\mathrm{d}}$} \\
\hline & & AMP & & OXA & & PEN & & MET $^{\mathbf{b}}$ & & EM & & $\begin{array}{l}\text { AU/mL } \\
\text { Activity }\end{array}$ & $\begin{array}{l}\text { AU/mg } \\
\text { Protein }\end{array}$ & $\begin{array}{l}\text { AU/mL } \\
\text { Activity }\end{array}$ & $\begin{array}{l}\text { AU/mg } \\
\text { Protein }\end{array}$ \\
\hline S. agalactiae & RPSAG1 & 0.25 & $\mathrm{~S}$ & 4.00 & $\mathrm{R}$ & 0.50 & I & 8.00 & $\mathrm{R}$ & 0.50 & I & 640 & 76.8 & 2560 & 204.8 \\
\hline S. agalactiae & RPSAG2 & 0.25 & $\mathrm{~S}$ & 4.00 & $\mathrm{R}$ & 0.25 & I & 16.00 & $\mathrm{R}$ & 0.25 & $\mathrm{~S}$ & 1280 & 76.8 & 5120 & 204.8 \\
\hline S. dysgalactiae & RPSD1 & 0.25 & $S$ & 8.00 & $\mathrm{R}$ & 0.25 & I & 8.00 & $\mathrm{R}$ & 0.25 & $S$ & 640 & 76.8 & 2560 & 204.8 \\
\hline S. dysgalactiae & RPSD2 & 0.25 & S & 4.00 & $\mathrm{R}$ & 0.25 & I & 16.00 & $\mathrm{R}$ & 0.25 & $S$ & 640 & 76.8 & 2560 & 204.8 \\
\hline S. dysgalactiae & RPSD3 & 0.25 & $S$ & 4.00 & $\mathrm{R}$ & 0.25 & I & 8.00 & $\mathrm{R}$ & 0.25 & $\mathrm{~S}$ & 640 & 76.8 & 2560 & 204.8 \\
\hline S. dysgalactiae & RPSD4 & 0.25 & $\mathrm{~S}$ & 4.00 & $\mathrm{R}$ & 0.50 & I & 16.00 & $\mathrm{R}$ & 0.50 & I & 640 & 76.8 & 2560 & 204.8 \\
\hline S. uberis & RPSU1 & 0.12 & $S$ & 8.00 & $\mathrm{R}$ & 0.25 & I & 16.00 & $\mathrm{R}$ & 0.25 & $S$ & 640 & 76.8 & 10240 & 204.8 \\
\hline S. uberis & RPSU2 & 0.25 & S & 8.00 & $\mathrm{R}$ & 0.25 & I & 16.00 & $\mathrm{R}$ & 0.25 & $\mathrm{~S}$ & 160 & 75.2 & 640 & 217.6 \\
\hline S. uberis & EDSU1 & 0.12 & $\mathrm{~S}$ & 8.00 & $\mathrm{R}$ & 0.25 & I & 32.00 & $\mathrm{R}$ & 0.25 & $\mathrm{~S}$ & 640 & 76.8 & 5120 & 204.8 \\
\hline S. uberis & EDSU2 & 0.25 & $\mathrm{~S}$ & 8.00 & $\mathrm{R}$ & 1.00 & I & 16.00 & $\mathrm{R}$ & 0.50 & I & 160 & 75.2 & 1280 & 217.6 \\
\hline S. aureus & RPSA1 & 0.12 & $S$ & 8.00 & $\mathrm{R}$ & 0.50 & $\mathrm{R}$ & 16.00 & $\mathrm{R}$ & 0.50 & $S$ & 640 & 76.8 & 1280 & 217.6 \\
\hline S. aureus & RPSA2 & 0.25 & $S$ & 8.00 & $\mathrm{R}$ & 0.50 & $\mathrm{R}$ & 16.00 & $\mathrm{R}$ & 0.50 & $\mathrm{~S}$ & 640 & 76.8 & 1280 & 217.6 \\
\hline S. aureus & EDSA & 0.25 & $\mathrm{~S}$ & 4.00 & $\mathrm{R}$ & 0.50 & $\mathrm{R}$ & 16.00 & $\mathrm{R}$ & 0.50 & $\mathrm{~S}$ & 0 & 0 & 0 & 0 \\
\hline S. aureus & EDSA0269 & 0.12 & $S$ & 8.00 & $\mathrm{R}$ & 0.50 & $\mathrm{R}$ & 16.00 & $\mathrm{R}$ & 0.50 & $S$ & 640 & 76.8 & 1280 & 217.6 \\
\hline S. epidermidis & RPSE1 & 0.25 & $S$ & 16.00 & $\mathrm{R}$ & 0.50 & $\mathrm{R}$ & 16.00 & $\mathrm{R}$ & 0.25 & $\mathrm{~S}$ & 2560 & 76.8 & 10240 & 204.8 \\
\hline E. coli & RPEC1 & 1.00 & $S$ & $>32$ & (R) & 32.00 & (R) & $>32.00$ & (R) & $>32$ & (R) & 0 & 0 & 0 & 0 \\
\hline E. coli & RPEC2 & 2.00 & $\mathrm{~S}$ & $>32$ & (R) & 32.00 & (R) & $>32.00$ & (R) & $>32$ & $(\mathrm{R})$ & 0 & 0 & 0 & 0 \\
\hline
\end{tabular}

ampicillin (AMP), oxacillin (OX), penicillin G (PEN), methicillin (MET), erythromycin (EM); sensitive (S), intermediate (I), resistant $(\mathrm{R})$;

${ }^{\mathrm{b}}$ MET interpretative data based on OX

No veterinary-specific interpretative criteria available for E.coli for OX, PEN, MET and EM, breakpoint interpretation is thus given in parentheses.

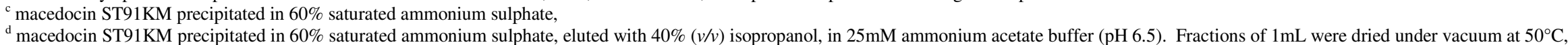

reconstituted to final volume of $1 \mathrm{~mL}$ with ammonium acetate buffer $(\mathrm{pH} 6.5)$ 
into the agar. Teat seal preparations combined with bacteriocin ST91KM, with and without $1 \%(\mathrm{w} / \mathrm{w})$ Tween 80, were carefully dispensed into the wells to ensure that the seal was in contact with the wall of the wells. The agar plates were incubated at $37^{\circ} \mathrm{C}$ overnight for $16 \mathrm{~h}$ and the zones of inhibition measured.

\section{RESULTS} Addition of macedocin ST91KM (229AU/mL) to $S . \mathrm{K}^{+} / \mathrm{L}$ recorded for untreated cells. agalactiae RPSAG2 after $5 \mathrm{~h}$ of growth, decreased the cell density from $\mathrm{OD}_{600 \mathrm{~nm}}=0.16$ to 0.10 within $1 \mathrm{~h}$ and remained at this level for a further $4 \mathrm{~h}$ (Fig. 1). Optical density readings of the control culture (no bacteriocin added) increased to $\mathrm{OD}_{600 \mathrm{~nm}}=1.21$ over $10 \mathrm{~h}$ (Fig. 1).

Optical density readings measured at $260 \mathrm{~nm}$ and $420 \mathrm{~nm}$ are presented in Table 2. Potassium levels of cells treated with macedocin ST91KM was $534 \mathrm{mg} \mathrm{K}^{+} / \mathrm{L}$ compared to $509 \mathrm{mg}$

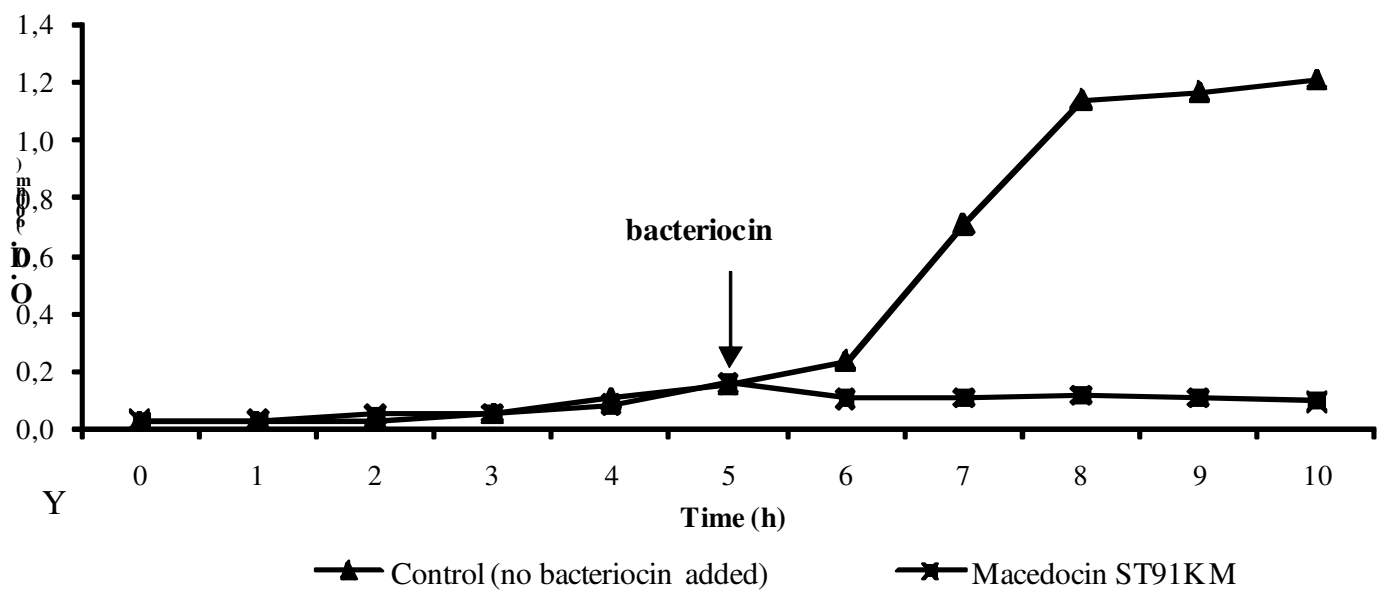

Figure 1. The effect of macedocin ST91KM on S. agalactiae RPSAG2. The arrow indicates the point at which macedocin ST91KM was added.

Table 2. Effect of macedocin ST91KM on the permeability of L. sakei LMG13558 cells

\begin{tabular}{llll}
\hline & $\begin{array}{l}\text { nucleotides } \\
(\mathbf{O . D .} 260 \mathbf{n m})\end{array}$ & $\begin{array}{l}\boldsymbol{\beta} \text {-galactosidase } \\
(\mathbf{O . D .} \text { 420nm })\end{array}$ & $\begin{array}{l}\text { Potassium ions } \\
(\mathbf{m g} / \mathbf{L})\end{array}$ \\
\hline Treated cells & 2.979 & 1.265 & 534 \\
Untreated cells & 0.624 & 0.116 & 509 \\
$\begin{array}{l}\text { Macedocin ST91KM, no } \\
\text { cells }\end{array}$ & 0.581 & 0.631 & 8 \\
\hline
\end{tabular}

Macedocin ST91KM adsorbed to both sensitive and nonsensitive cells (Table 1). Sixty-six percent of the peptide adsorbed to L. sakei LMG13558. However, $66 \%$ of the peptide also adsorbed to non-sensitive strains of Enterococcus faecalis (BFE1071 and FAIR-E92) and Streptococcus caprinus (ATCC700066). Limited, or very little adsorption (up to $33 \%$ ) of macedocin ST91KM has been recorded for the other resistant strains (Table 1).

Treatment of cells with macedocin ST91KM at $10-60^{\circ} \mathrm{C}$ and at $\mathrm{pH} 8$ and 10 lead to a significant increase in adsorption (Table 3). Adsorption of the peptide to target cells decreased from 66 to $33 \%$ below $37^{\circ} \mathrm{C}$ and was completely inhibited at $4^{\circ} \mathrm{C}$. 
Pieterse, R. et al.

Table 3. Effect of $\mathrm{pH}$, temperature, surfactants and salts on the adsorption of macedocin ST91KM to L. sakei LMG 13558

\begin{tabular}{|c|c|}
\hline & Adsorption (\%) \\
\hline Control (not treated) & 66 \\
\hline \multicolumn{2}{|l|}{ Effect of $\mathrm{pH}$} \\
\hline 2,4 and 6 & 33 \\
\hline 8 and 10 & 66 \\
\hline \multicolumn{2}{|l|}{ Effect of temperature $\left({ }^{\circ} \mathrm{C}\right)$} \\
\hline 4 & 0 \\
\hline 10,25 , and 30 & 33 \\
\hline 37 and 45 & 66 \\
\hline 60 & 33 \\
\hline \multicolumn{2}{|l|}{ Treatment with $1 \%$} \\
\hline Na-acetate & 66 \\
\hline $\mathrm{Na}_{2} \mathrm{CO}_{3}$ & 0 \\
\hline EDTA(-Na) & 33 \\
\hline SDS, Triton X-100 and Triton X-114 & 66 \\
\hline B-mercaptoethanol, $80 \%$ ethanol and methanol & 33 \\
\hline Chloroform & 66 \\
\hline $\mathrm{NaCl}, \mathrm{K}_{2} \mathrm{HPO}_{4}, \mathrm{KH}_{2} \mathrm{PO}_{4}, \mathrm{KCl}$ and $\mathrm{NH}_{4}$-citrate & 33 \\
\hline $\mathrm{MgCl}_{2}$ & 0 \\
\hline $\mathrm{KI}$ & 0 \\
\hline Tris & 33 \\
\hline
\end{tabular}

Addition of inorganic and organic salts reduced adsorption of the bacteriocin. $\mathrm{MgCl}_{2}, \mathrm{KI}$ and $\mathrm{Na}_{2} \mathrm{CO}_{3}$ salts completely prevented adsorption of the peptide to target cells (Table 3 ). SDS, Triton X-100 and Triton X-114 did not affect adsorption of macedocin ST91KM to target cells, while $\beta$ -

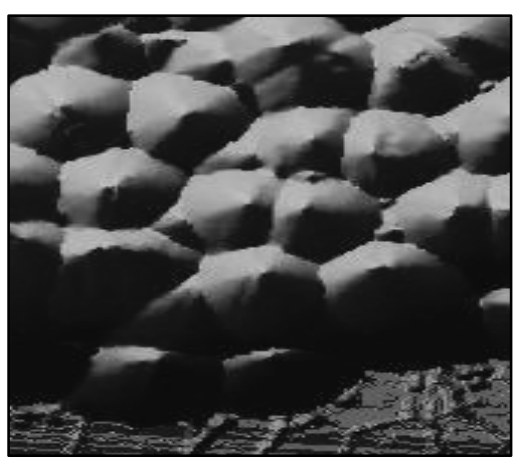

(A) Untreated cells mercaptoethanol, $80 \%$ ethanol and methanol reduced adsorption to $33 \%$. Chloroform had no effect on adsorption.

Cells of $S$. agalactiae RPSAG2 treated with partially purified macedocin ST91KM (approximately 2000AU/mL) were deformed and had irregular surfaces compared to cells that have not been treated (Fig. 2).

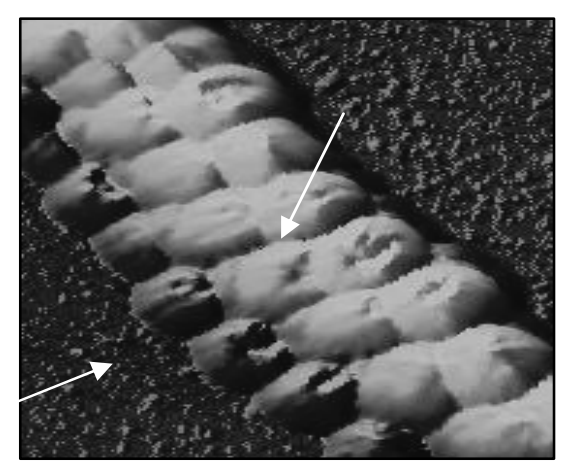

(B) Cells treated with macedocin ST91KM

Figure 2. Changes in cell morphology of $S$. agalactiae RPSAG2 treated with macedocin ST91KM. A: before treatment, B: after treatment. The arrow indicates irregularity on the cell surface. 
Susceptibility of pathogens to antibiotics is shown in Table 4. Data were interpreted based on veterinary-specific criteria, except for oxacillin against streptococci, which was interpreted based on data obtained from trials on humans (24). All isolates were resistant to methicillin and oxacillin, but susceptible to ampicillin (Table 4). Streptococci showed intermediate resistance to penicillin G. Three of the ten streptococci tested had intermediate MICs against erythromycin. S. agalactiae RPSAG1, S. dysgalactiae RPSD4 and $S$. uberis EDSU2 displayed the highest MICs against penicillin G. Strains of $S$. aureus and coagulase-negative staphylococci (CNS), S. epidermidis, were resistant to penicillin G. The staphylococci were all susceptible to erythromycin. The only Gram-negative mastitis pathogens tested was E. coli. Both isolates were resistant to oxacillin, methicillin and erythromycin. The strains of E. coli tested were susceptible to ampicillin.

Antimicrobial susceptibility to the macedocin ST91KM is shown in Table 4. Two preparations of macedocin ST91KM were used: ST91KM precipitate (ST91KMppt) and ST91KM concentrate (ST91KMcon). The minimum concentration of macedocin ST91KM required to completely inhibit visible growth of the sensitive strains was $74.8 \mathrm{AU} / \mathrm{mg}$ protein for ST91KMppt and 216AU/mg protein for ST91KMcon. The purification and concentration of macedocin ST91KM in ST91KMcon resulted in an average increase of $63.5 \%$ in the AU/mg protein. Only Gram-positive isolates (93.3\%) were sensitive to the bacteriocin. Of the four $S$. aureus strains tested, three were sensitive to macedocin ST91KM.

S. agalactiae RPSAG2 and S. epidermidis RPSE1 were the most sensitive, as growth was completely inhibited after a 1:64 (1280AU/mL) and 1:128 (2560AU/mL) dilution, respectively. Most other sensitive strains were inhibited at a dilution of 1:32 (640AU/mL). Similar results were obtained with the ST91KM concentrate when tested against $S$. agalactiae RPSAG2 and S. epidermidis RPSE1. The ST91KM concentrate inhibited the growth of these pathogens at dilutions of $1: 512(10240 \mathrm{AU} / \mathrm{mL})$ and 1:256 (5120AU/mL), respectively.
The activity of the bacteriocin added to the teat seal formulation was $160 \mathrm{AU} / \mathrm{mL}$ macedocin ST91KM ppt per gram. Clear zones of inhibition against the test organism $S$. agalactiae (RPSAG2) were observed (data not shown). No inhibitory effect was seen in wells that contained the teat seal only. Macedocin ST91KM was released from the teat seal preparation without Tween $80(1 \%$, w/w) showing an inhibition zone of $14 \mathrm{~mm}$, slightly smaller than the inhibition zone without the addition of Tween 80 .

\section{DISCUSSION}

A decrease in cell growth, from $10^{6} \mathrm{CFU} / \mathrm{mL}$ to $10^{5} \mathrm{CFU} / \mathrm{mL}$ after $1 \mathrm{~h}$ of addition of macedocin ST91KM (Fig. 1) suggests that its mode of activity is bactericidal. A bactericidal mode of activity has been demonstrated for lantibiotics lacticin 3147 (19) and macedocin ACA-DC 198 (7). Addition of $300 \mathrm{AU} / \mathrm{mL}$ lacticin 3147 to cells of Lactococcus lactis subsp. cremoris HP resulted in a $30 \%$ decline in viable cell numbers within $15 \mathrm{~min}$. An increase in potency of lacticin 3147 to $1200 \mathrm{AU} / \mathrm{mL}$ resulted in complete repression of growth (19). A similar mode of action was demonstrated for macedocin ACA-DC 198 against L. sakei LMG13558. Treatment of the cells with macedocin ACADC198 (400AU/mL) lowered the cell numbers from $10^{8}$ to $10^{7} \mathrm{CFU} / \mathrm{mL}$ after $1 \mathrm{~h}$. Treatment of the target cells with higher levels of macedocin ACA-DC198 (800AU/mL) did not result in a more rapid reduction of viable cell numbers (7).

Optical density readings measured at $260 \mathrm{~nm}$ and $420 \mathrm{~nm}$ increased after addition of macedocin ST91KM (Table 2), suggesting that nuclear material and $\beta$-galactosidase leaked from damaged cells. Potassium levels were only slightly higher at $534 \mathrm{mg} \mathrm{K}^{+} / \mathrm{L}$, compared to untreated cells $(509 \mathrm{mg}$ $\mathrm{K}^{+} / \mathrm{L}$ ). This was attributed to leakage from the cells of $L$. sakei (LMG13558). Similar results have been reported for buchnerin LB, a bacteriocin produced by Lactobacillus buchneri (38). However, a much weaker efflux of $\mathrm{K}^{+}$was reported for macedocin ST91KM.

The mode of action of macedocin ST91KM did not only depend on adsorption, as sensitive and non-sensitive strains 
revealed similar levels of adsorption of the peptide (Table 1). Yildirim et al. (38) reported a high percentage adsorption of buchericin LB to resistant strains of L. lactis (94\%), Pediococcus cerevisiae (100\%) and S. aureus (80\%). Manca de Nadra et al. (18), on the other hand, reported weak adsorption of pediocin N5p to resistant strains (13 to 20\%) and higher adsorption to sensitive strains (30-100\%). This indicated that the bactericidal action of pediocin N5p is dependent on specific receptors on sensitive strains.

SDS, Triton X-100 and Triton X-114 did not affect adsorption of macedocin ST91KM to target cells, while the solvents, $\beta$-mercaptoethanol, $80 \%$ ethanol and methanol reduced adsorption to $33 \%$. This suggests that the binding sites on target cells may have lipid moieties.

Deformation of target cells treated with macedocin ST91KM suggests that the peptide forms pores in the cell membrane. This is in line with the mode of action of other bacteriocins, such as lacticin 3147 (19).

All isolates were resistant to methicillin and oxacillin, but susceptible to ampicillin (Table 4). Streptococci showed intermediate resistance to penicillin G. This is in agreement with findings reported by Rossitto et al. (29) for isolates of $S$. dysgalactiae and S. uberis, where $1.3 \%$ and $50.4 \%$ of isolates showed intermediate resistance to penicillin, respectively. However, Guérin-Faublée et al. (8) reported that only S. uberis (14\% of isolates tested) had an intermediate MIC for penicillin G. Other strains of S. agalactiae and S. dysgalactiae were susceptible to penicillin $G(8)$. Three of the ten streptococci tested had intermediate MICs against erythromycin. Interestingly, these strains ( $S$. agalactiae RPSAG1, $S$. dysgalactiae RPSD4 and S. uberis EDSU2) also displayed the highest MICs against penicillin G.

Strains of S. aureus and coagulase-negative staphylococci, Staphylococcus epidermidis, were resistant to penicillin G. This is in agreement with findings reported by Gentilini et al. (6) and Moroni et al. (20). Oxacillin is recommended as the antimicrobial agent to evaluate susceptibility to methicillin and cloxacillin (23). The MIC data suggests that all the isolates tested are also resistant to cloxacillin, even though the antibiotic was not tested. Most antimicrobial products currently used to treat and prevent intramammary infections in cows contain $\beta$-lactam penicillins, i.e. penicillin, cloxacillin and ampicillin (11). According to the antimicrobial susceptibility patterns of the isolates tested, ampicillin would be the drug of choice to treat both Gram-negative and Grampositive bacterial infections. However, the Clinical and Laboratory Standards Institute state that methicillin (oxacillin)resistant staphylococci should be considered resistant to all $\beta$ lactams (including ampicillin), regardless of in vitro results (23). One CNS, S. epidermidis was susceptible to ampicillin. CNS strains are often referred to as minor pathogens (27). However, in a study by Rajala-Scultz et al. (28), 77\% of all isolates associated with bovine mastitis were CNS and $77.3 \%$ of these strains were resistant to ampicillin.

Both strains of E. coli were resistant to oxacillin, methicillin and erythromycin. This is not unusual, as Gramnegative strains are not usually susceptible to these antibiotics (23). E. coli strains tested were susceptible to ampicillin. Some strains of $E$. coli that have been isolated from mastitis infections are resistant to ampicillin $(13,34)$.

The bactericidal action of some bacteriocins such as lantibiotics is to form pores in the membrane of sensitive bacterial cells in a specific target-mediated manner, binding to membrane-bound cell wall receptors (12). It is thus possible that the insensitive strain of $S$. aureus does not have the specific cell wall receptors required for binding to macedocin ST91KM. Variations in the sensitivity of different strains of $S$. uberis could be attributed to slight differences in the initial inoculum size.

Bacteriocins that have been considered as antimicrobial agents against mastitis pathogens include the lantibiotics lacticticin 3147 and nisin (30,33). Lacticin 3147 and nisin are both broad-spectrum lantibiotics, exhibiting antibacterial activity against Gram-positive mastitis pathogens. Steptococci are more sensitive to these lantibitics than $S$. aureus as was the case for macedocin $(3,30)$. The potency of lacticin 3147 against S. dysgalactiae reported by Ryan et al. (30) would appear to be significantly higher at $10240 \mathrm{AU} / \mathrm{mL}$ than that of 
the macedocin ST91KM concentrate at 2560AU/mL. Further purification of macedocin ST91KM would be necessary to improve potency.

Given that most of the mastitis pathogens tested showed resistance to antibiotics commonly used in dry cow and lactation therapeutics ( $\beta$-lactam penicillins), this macedocin could be a possible candidate for an alternate antimicrobial agent. Methicillin-resistance in $S$. aureus (MRSA) is a widespread problem (32) and the antimicrobial susceptibility data would suggest that the $S$. aureus pathogens isolated from bovine milk samples are methicillin-resistant. The risk of contaminated food products containing MRSA entering the food chain could increase the risk of the transfer of resistance genes to human $S$. aureus isolates (15). The development of bacteriocins as antimicrobial agents against pathogens, especially those resistant to therapeutic antibiotics, should be considered. A comparative study evaluating the effectiveness of the bacteriocins nisin and mutacin B-Ny266 and the antibiotics oxacillin and vancomycin have shown that these bacteriocins are at least as effective against oxacillin-resistant S. aureus strains (21).

Dry cow therapy is recommended practice for all cows at the end of lactation. Dry cow therapy would involve the administration of antibiotics in a prophylactic manner to reduce the likelihood of new infections developing during this period. Inert teat sealants have been used in combination with antibiotics such as cloxacillin (2), the lacticin 3147 (30) and alone (1) for dry cow therapy.

Given that macedocin ST91KM was effective at inhibiting various mastitis pathogens, it was incorporated into a teat seal formulation $(65 \%, \mathrm{w} / \mathrm{w}$, bismuth subnitrate in paraffin base) to determine if macedocin ST91KM was effectively released to inhibit target organisms. Clear zones of inhibition against the test organism $S$. agalactiae (RPSAG2) were observed in the teat seal formulation containing macedocin ST91KM. The activity of the bacteriocin added to the teat seal formulation was 160AU/mL macedocin ST91KM ppt per gram. No inhibitory effect was seen in wells that contained the teat seal only. Ryan et al. (30) performed a similar evaluation incorporating lacticin 3147 into a teat seal, but found that unless Tween $80(2 \%$ w/w) was added; no inhibitory effect was seen, indicating that this bacteriocin was hydrophobic. Macedocin ST91KM was however released from the teat seal preparation without Tween $80(1 \%$, w/w) showing an inhibition zone of $14 \mathrm{~mm}$, slightly smaller than the inhibition zone without the addition of Tween 80 .

In conclusion, the action of macedocin ST91KM resulted in efflux of cellular components in sensitive strains. The peptide adsorbed to both sensitive and non-sensitive cells, indicating that activity is not species-specific but rather dependent on specific cell-surface receptors. Binding sites for the peptide could be lipid in nature, as the addition of solvents reduced adsorption. Salts prevented the adsorption of macedocin ST91KM to target cells, possibly due to competitive ion adsorption on the cell surface. Optimal adsorption of macedocin ST91KM was recorded at physiological $\mathrm{pH}$ and temperature, suggesting that the peptide could be included in a teat seal. Macedocin ST91KM is also heat stable remaining active at $100^{\circ} \mathrm{C}(26)$. This may be an important consideration to ensure that macedocin ST91KM would remain active after storage at a variety of storage condition in a final teat seal product. Macedocin ST91KM could potentially be used as an antimicrobial agent against pathogens associated with mastitis due the rapid bacteriocidal mode of action against the mastitis pathogen $S$. agalactiae RPSAG2. In vivo studies would however be necessary to fully evaluate the effectiveness of this bacteriocin and its possible synergetic effect with currently applied antibiotics.

\section{ACKNOWLEDGEMENTS}

This work was supported by a grant from the National Research Foundation (NRF) of South Africa. Dr. Svetoslav D. Todorov received a post-doctoral grant from the Claude Leon Foundation, Cape Town, South Africa. Dr. Martina Meinken from Central Analytical Facilities, AFM unit, University of Stellenbosch for performing Atomic Force Microscopy. 
Pieterse, R. et al.

\section{REFERENCES}

1. Berry, E.A.; Hillerton, J.E. (2002). The effect of an intramammry teat seal on new intramammry infections. J. Dairy Sci., 85: 2512-2520.

2. Bradley, A.; Newton, H.; Benchaoui, H.; Tilt, N.; Cracknell, V.; Rowan, T. (2005). Orbeseal ${ }^{\circledR}$ and Orbenin ${ }^{\circledR}$ for the treatment of intra-mammary infections at drying off and prevention of new infections during the dry period and early lactation in dairy cows. pp. 339-344 in H. Hogeveen (Ed.): Mastitis in Dairy Production Current Knowledge and Future Solutions. Wageningen Academic Publishers, The Netherlands.

3. Broadbent, J.R.; Chou, Y.C.; Grilles, K.; Kondo, J.K. (1989). Nisin inhibits several gram-positive, mastitis-causing pathogens. J. Dairy Sci., 72: 3342-3345.

4. Crist, W.L.; Harmon, R.J.; O’Leary, J.; McAllister, A.J. (1997). Mastitis and its control. Available from: http://www.ca.uky.edu/agc/pubs/asc/asc140/asc140.pdf. [Accessed 11 June 2007].

5. Davidse, E.; Balla, E.; Holzapfel, W.H.; Muller, C.J.C.; Cloete, S.W.P.; Dicks, L.M.T. (2004). Peptide AS-48 (Enterococcus faecalis) for the prevention and treatment of mastitis in dairy cows. Online J. Veterinary Res., 8: 22-32.

6. Gentilini, E.; Denamiel, G.; Bentancor, A.; Rebuelto Fermepin, M.R.; De Torres, R.A. (2002). Antimicrobial susceptibility of coagulase-negative staphylococci isolated from bovine mastits in Argentina. J. Dairy Sci., 85: 1913-1917.

7. Georgalaki, M.D.; Van den Bergh, E.; Kritikos, D.; Devreese, B.; Van Beeuman, J.; Kalantzopoulos, G.; De Vuyst, L.; Tsakalidou, E. (2002). Macedocin, A food-grade lantibiotic produced by Streptococcus macedonicus ACA-DC 198. Appl. Environ. Microbiol., 68: 5891-5903.

8. Guérin-Faublée, V.; Tardy, F.; Bouveron, C.; Carret, G. (2002). Antimicrobial susceptibility of Streptococcus species isolated from clinical mastitis in dairy cows. Int. J. Antimicrob. Agents, 19: 219-226.

9. Hébert, A.; Sayasith, K.; Sénéchal, S.; Dubreuil, P.; Lagacé, J. (2000) Demonstration of intracellular Staphylococcus aureus in bovine mastitis alveolar cells and macrophages isolated from naturally infected cow milk. FEMS Microbiol. Letts., 193: 57-62.

10. Hsu, C.A.; Yu, R.C.; Chou, C.C. (2005) Production of $\beta$-galatosidase by bifidobacteria as influenced by various culture conditions. Int. J. Food Microbiol., 104: 197-200.

11. IVS Desk Reference (2005). Cape Town: CTP Book Publishers.

12. Jack, R.W.; Tagg, J.R.; Ray, B. (1995). Bacteriocins of gram-positive bacteria. Microbiol. Revs., 59: 171-200.

13. Kaspar, H. (2006). Results of the antimicrobial agent susceptibility study raised in a representative, cross-sectional monitoring study on a national basis. Int. J. Med. Microbiol., 296: 69-79.

14. Khan, S.A.; Nawaz, M.S.; Khan, A.A.; Steele, R.S.; Cerniglia, C.E. (2000). Characterization of erythromycin-resistant methylase genes from multiple antibiotic resistant Staphylococcus spp isolated from milk samples of lactating cows. Am. J. Vet. Res., 61: 1128-1132.

15. Lee, J.H. (2003). Methicillin (Oxacillin)-resistant Staphylococcus aureus strains isolated from major food animals and their potential transmission to humans. Appl. Environ. Microbiol., 69: 6489-6494.

16. Loch, I.M.; Geln, K.; Zadoks, R.N. (2005). Macrolide and lincosamide resistance genes of environmental streptococci from bovine milk. Vet. Microbiol., 111: 133-138.

17. Lüthje, P.; Schwarz, S. (2006). Antimicrobial resistance of coagulasenegative staphylococci from bovine subclincial mastitis with particular reference to macrolide-lincosamide resistance phenotypes and genotypes. J. Antimicrob. Agents. Chemother., 57: 966-969.

18. Manca de Nadra, M.C.; Sandino de Lamellas, D.; Strasser de Saad, A.M. (1998). Pediocin N5p from Pediococcus pentosaceus, adsorption on bacterial strains. Int. J. Food Microbiol., 39: 79-85.

19. McAuliffe, O.; Ryan, M.P.; Ross, R.P.; Hill, C.; Breuwer, P.; Abee, T. (1998). Lacticin 3147, a broad-spectrum bacteriocin which selectively dissipates the membrane potential. Appl. Environ. Microbiol., 64: 439445.

20. Moroni, P.; Vellere, F.; Antonini, M.; Pisoni, G.; Ruffo, G.; Carli, S. (2004). Antibiotic susceptibility of coagulase-negative staphylococci isolated from goats' milk. Int. J. Antimicrob. Agents, 23: 637-640.

21. Mota-Meira, M.; LaPointe, G.; Lacroix, C.; Lavoie, M.C. (2000). MICs of mutacin B-Ny266, nisin A, vancomycin, and oxacillin against bacterial pathogens. Antimicrob. Agents Chemother., 44: 24-29.

22. Nagy, Z.; Kiss, T.; Szentirmai, A.; Biro, S. (2001). $\beta$-Galactosidase of Penicillium chrysogenum: production, purification and characterisation of the enzyme. Prot. Express. Purific., 21: 24-29.

23. National Committee for Clinical Laboratory Standards Institute. (2002). Performance Standards for Antimicrobial Disk and Dilution Susceptibility Tests for Bacteria Isolated from Animals; Approved Standard. 2nd ed. NCCLS document M31-A2, Wayne, Pennsylvania, USA.

24. National Committee for Clinical Laboratory Standards Institute. (2004). Performance Standards for Antimicrobial Disk and Dilution Susceptibility Tests for Bacteria Isolated from Animals, Informational Supplement. NCCLS document M31-S1, Wayne, Pennsylvania, USA.

25. Philot, W.N.; Nickerson, S.C. (1999). Mastitis: Counter Attack. Westfalia Surge LLC: Illinois, USA.

26. Pieterse, R.; Todorov, S.D.; Dicks, L.M.T. (2008). Bacteriocin ST91KM, produced by Streptococcus gallolyticus subsp. macedonicus ST91KM, is a narrow-spectrum peptide active against bacteria associated with mastitis in dairy cattle. Can. J. Microbiol., 54: 525-531.

27. Quinn, P.J.; Carter, M.E.; Markey, B.; Carter, G.R. (1999). Clinical Veterinary Microbiology, Harcourt Publishers Ltd.: London.

28. Rajala-Schultz, P.J.; Smith, K.L.; Hogan, J.S.; Love, B.C. (2004). Antimicrobial susceptibility of mastitis pathogens from first lactation and older cows. Vet. Microbiol., 102: 33-42. 
29. Rossitto, P.V.; Ruiz, L.; Kikuchi, Y.; Glenn, K.; Luiz, K.; Watts, J.L.; Cullor, J.S. (2002). Antibiotic susceptibility patterns for environmental streptococci isolated from bovine mastitis in central California dairies. $J$. Dairy Sci., 85: 132-138.

30. Ryan, M.P.; Meaney, W.J.; Ross, R.P.; Hill C. (1998). Evaluation of lacticin 3147 and a teat seal containing this bacteriocin for inhibition of mastitis pathogens. Appl. Environ. Microbiol., 64: 2287-2290.

31. Sambrook, J.E.; Eritsch, F.; Mariatis, J. (1989). Molecular Cloning: A Laboratory Manual. 2nd ed. New York: Cold Spring Harbour Laboratory Press, Cold Spring Harbour.

32. Scott, G. (2005) Antibiotic resistance. Medicin., 33: 47-51.

33. Sears, P.M.; Smith, B.S.; Stewart, W.K.; Gonzalez, R.N.; Rubino, S.D.; Gusik, S.A.; Kuliusek, E.S.; Projam, S.J.; Blakburn, P. (1992). Evaluation of a nisin-based germicidal formulation on teat skin of live cows. J. Dairy Sci., 75: 3185-3190.

34. Srinivasan, V.; Gillespie, B.E.; Lewis, M.J.; Nguyen, L.T.; Headrick, S.I.; Schukken, Y.H.; Oliver, S.P. (2007). Phenotypic and genotypic antimicrobial resistance patterns of Escherichia coli isolated from dairy cows with mastitis. Vet. Microbiol., 124; 319-328.

35. Todorov, S.; Vaz-Velho, M.; Gibbs, P. (2004). Comparation of two methods for purification of plantaricin ST31, a bacteriocin produced from Lactobacillus plantarum ST31. Braz. J. Microbiol., 35: 157-160.

36. Todorov, S.D. (2008). Bacteriocin production by Lactobacillus plantarum AMA-K isolated from Amasi, a Zimbabwean fermented milk product and study of adsorption of bacteriocin AMA-K to Listeria spp. Braz. J. Microbiol., 38: 178-187.

37. Twomey, D.P.; Wheelcock, A.I; Flynn, J.; Meaney, W.J.; Hill, C.; Ross, R.P. (2000)._Protection against Staphylococcus aureus mastitis in dairy cows using a bismuth-based teat seal containing the bacteriocin, lacticin 3147. J. Dairy Sci., 83: 1981-1988.

38. Yildrim, Z.; Avşar, Y.K.; Yildrim, M. (2002). Factors affecting the adsorption of buchnericin LB, a bacteriocin produced by Lactobacillus buchneri. Microbiol. Res., 157: 103-107. 